\title{
Dose- and time-dependent expression patterns of zebrafish orthologs of selected E2F target genes in response to serum starvation/replenishment
}

\author{
Ceren Sucularli $\cdot$ Serif Senturk · Mehmet Ozturk • \\ Ozlen Konu
}

Received: 13 June 2010/Accepted: 15 November 2010/Published online: 30 November 2010

(C) Springer Science+Business Media B.V. 2010

\begin{abstract}
Targets of E2F transcription factors effectively regulate the cell cycle from worms to humans. Furthermore, the dysregulation of E2F transcription modules plays a highly conserved role in cancers of human and zebrafish. Studying E2F target expression under a given cellular state, such as quiescence, might lead to a better understanding of the conserved patterns of expression in different taxa. In the present study, we used literature searches and phylogeny to identify several targets of E2F transcription factors that are known to be serum-responsive; namely, PCNA, MYBL2, MCM7, TYMS, and CTGF. The transcriptional serum response of zebrafish orthologs of these genes were quantified under different doses (i.e., 0, 0.1, 1, 3, and 10\% FBS) and time points (i.e., 6, 24 and 48 hours, h) using quantitative RT-PCR (qRT-PCR) in the zebrafish fibroblast cells (ZF4). Our results indicated that mRNA expression of zebrafish pcna, mybl2, $m c m 7$ and tyms drastically decreased while that of ctgf increased with decreasing serum levels as observed in mammals. These genes responded to serum starvation at 24 and $48 \mathrm{~h}$ and to the mitogenic stimuli as early as $6 \mathrm{~h}$ except for $\operatorname{ctg} f$ whose expression was significantly altered at $24 \mathrm{~h}$. The zebrafish $\mathrm{Mcm} 7$ protein levels also were modulated by serum starvation/replenishment. The present study provides a
\end{abstract}

Electronic supplementary material The online version of this article (doi:10.1007/s11033-010-0531-2) contains supplementary material, which is available to authorized users.

C. Sucularli · S. Senturk · M. Ozturk · O. Konu ( $\square)$

Department of Molecular Biology and Genetics,

Faculty of Science, Bilkent University, 06800 Ankara, Turkey

e-mail: konu@fen.bilkent.edu.tr

M. Ozturk

INSERM-Université Joseph Fourrier,

CRI U823, Grenoble 38042, France foundation for the comparative analysis of quantitative expression patterns for genes involved in regulation of cell cycle using a zebrafish serum response model.

Keywords Cell cycle analysis - MTT analysis . Phylogenetics - Real-time qRT-PCR .

Serum/wound response $\cdot \mathrm{ZF} 4$

Abbreviations
$\begin{array}{ll}\text { ZF4 } & \text { Zebrafish embryonic cell line } \\ \text { FBS } & \text { Fetal bovine serum } \\ \text { tyms } & \text { Thymidylate synthetase } \\ \text { mybl2 } & \text { Myeloblastosis oncogene-like } 2 \\ \text { pcna } & \text { Proliferating cell nuclear antigen } \\ \text { ctgf } & \text { Connective tissue growth factor } \\ \text { mcm7 } & \text { Minichromosome maintenance deficient } 7 \\ \text { ef1 } \alpha & \text { Elongation factor 1-alpha }\end{array}$

\section{Introduction}

The comparison of expression patterns across different taxa helps to identify the extent of the contribution by a particular signaling/transcription module into the regulation of cell cycle and tumor progression [1]. E2F transcription factors are crucially important in cell cycle regulation and share conserved regulatory motifs in worms, insects, fish and mammals [2]. The dysregulation of E2F transcription modules might promote tumors as revealed by the highly conserved signatures obtained from functional gene-set enrichment analyses of the zebrafish and human cancer microarray datasets [1, 3]. Indeed, the zebrafish has recently emerged as a preferable vertebrate model 
organism for demonstrating the striking conservation of liver cancer expression profiles between zebrafish and human [1, 4]. Furthermore, zebrafish were used as a promising xenotransplantation model for human malignant cell lines [5, 6].

The quiescent state induced by serum starvation represents a powerful model for studying the mitogen dependency of cancer cells [7, 8]. An increased wound/serum response has already been associated with a worse prognosis in multiple epithelial cancers [9] while microarray studies of human cancer cells and zebrafish cell lines have helped to characterize the global transcriptional signature for serum response [10, 11]. The strong association between the cell cycle, E2F transcription factors and mitogen levels has been well-established for mammals: The reduced serum conditions result in decreased rates of proliferation followed by an arrest in the G1 phase of the cell cycle [12]; and E2F1, among other transcriptional regulators, drives quiescent cells into the $S$ phase $[13,14]$. In serum-replenished human cell lines, an increase in E2F1 at the $\mathrm{G} 1$ to $\mathrm{S}$ phase transition also has been detected [15]. However, the cellular aspects of the quiescent state induced by serum starvation are not well characterized in zebrafish.

Similarly, the expression response of E2F targets to serum starvation/replenishment has been investigated using large scale transcriptional factor binding site and expression studies in mammals [16, 17]. For instance, among others, PCNA, TYMS, MCM2-7, MYBL2 were shown to be readily induced in mammals by growth-inducing mitogenic stimuli, such as increased serum concentrations and/or by E2F signaling while $C T G F$ was repressed by E2F signaling [16-22]. In zebrafish, pcna, tyms, mybl2 and ctgf were studied previously, yet mostly in the context of embryonic development and tissue expression. pcna has been shown as a cell proliferation marker in zebrafish embryonic intermediate cell mass and in the highly proliferating cell subgroup of adult kidney cells [23]. The zebrafish ctgf is expressed in the zebrafish embryonic stages [24, 25], while mybl2 has been shown to be involved in cancer progression as well as cell proliferation, similar to human homolog [26, 27]. Previous studies have shown the importance of Pcna as well as Mcm proteins in zebrafish cell proliferation in zebrafish retina [28, 29]. The expression of pcna and $m c m 5$ were shown to be correlated, and proposed as the markers of cell proliferation also in zebrafish models [28]. Although several components of the minichromosome maintenance (Mcm) complex including $m c m 7$ have been identified in an insertional mutagenesis screen in zebrafish, only the expression of $\mathrm{mcm} 5$ has been characterized in detail [28, 30]. Accordingly, the time- and dose-dependent serum responses for the abovementioned genes have not been analyzed quantitatively in the literature.

In the present study, we hypothesized that serum starvation might lead to quiescence in zebrafish fibroblasts and thus modulate the strength and magnitude of expression response of E2F target orthologs in a dose- and timedependent manner [16, 18, 19, 21, 31]. Therefore, we first demonstrated the phylogenetic conservation of the selected orthologs of mammalian E2F targets in zebrafish. Next, we established a serum-response model using zebrafish embryonic fibroblast cells (ZF4) based on cell viability assays. Moreover, the levels of cell proliferation and cell cycle progression were determined when ZF4 cells were serum-replenished based on BrdU incorporation measurements and flow cytometric analyses, respectively. We then performed real-time qRT-PCR analysis of these selected genes under different dose- and time-dependent serum starvation and serum replenishment conditions. Our findings indicated that $\mathrm{ZF} 4$ cells went into a reversible state of quiescence upon serum depletion as evidenced by multiple cellular parameters, and thus could be used as a quiescence model for comparative expression studies among vertebrates. In addition, mRNA expression of mybl2, tyms, pcna, mcm 7 and ctgf responded to serum starvation/ replenishment in a manner comparable to that observed in mammals based on the information from existing literature. This study provides a foundation for the comparative analysis of expression patterns for genes involved in cell cycle regulation using the $\mathrm{ZF} 4$ cell line serum response model.

\section{Materials and methods}

Selection of the gene set and primer design

To obtain a more comprehensive understanding of the zebrafish serum-dependent cell signaling, we strategically selected a set of genes known to be repressed under serum deprivation and/or upregulated by E2F1 [16, 18, 19, 21, 31, 32]. Accordingly, zebrafish orthologs of TYMS, MYBL2, PCNA and MCM7 were selected for phylogenetics and qRT-PCR studies. In addition, CTGF, a likely secondary target repressed by E2F also was selected. The decrease in $C T G F$ mRNA levels by E2Fs was confirmed with Northern Blot analyses, and the regulation of CTGF transcription was likely to be indirect shown by cycloheximide treatment [32]. Primers were designed for real-time qRT-PCR analysis using Primer 3 v.0.4.0 (http://frodo.wi.mit.edu) (Table 1) [33].

Amino acid sequence alignments and phylogenetic analysis

The protein sequences extracted from NCBI (http://www. ncbi.nlm.nih.gov/) and ENSEMBL (http://www.ensembl. org/index.html) databases were aligned using ClustalW 
Table 1 List of primer pairs and the amplification efficiencies of the primers

\begin{tabular}{|c|c|c|c|}
\hline Gene name & Forward primer & Reverse primer & Primer efficiency \\
\hline mybl2 & 5'-CCCACACTGAAGGAGGTGAT-3' & 5'-CTCCTTTACTGCCCTTGCTG-3' & 1.89 \\
\hline pcna & 5'-AGCCTGTCATCTGTGGGATT-3' & 5'-TGGTAAAGCTAAGGCCCAAA-3' & 1.85 \\
\hline$m c m 7$ & 5'-GAGATTTACGGCCATGAGGA-3' & 5'-GGTGTACTGACTGCGTGGAG-3' & 2 \\
\hline tyms & 5'-TGCTAACGGCTCCAGAGAGT-3' & 5'-CATGATGATCCTTCGGTCCT-3' & 1.86 \\
\hline $\operatorname{ctg} f$ & 5'-ACCAATGACAACCGTGAGTG-3' & 5'-GGTAGTGGTACAGCCGGAAA-3' & 1.78 \\
\hline efla & 5'-CCCTGGACACAGAGACTTCA-3' & 5'-CAGCCTCAAACTCACCAACA-3' & 1.81 \\
\hline
\end{tabular}

[34] and the percent amino acid identity was calculated. The amino acid sequences provided in Table S1 for the Tyms, Mybl2, Pcna, Ctgf and Mcm7 proteins were used for generating the bootstrapped neighbor-joining phylogenetic trees using MEGA version 4 [35] for the following species: human (Hs), rat $(\mathrm{Rn})$, mouse $(\mathrm{Mm})$, chicken $(\mathrm{Gg})$, cow (Bt), salmon (Ss), stickleback (Ga), green spotted puffer fish (Tn), zebrafish (Dr), western clawed frog (Xt), fugu (Tr) and medaka (Ol).

\section{Cell culture}

The zebrafish embryonic fibroblast (ZF4; ATCC, CRL2050) [36] cells were cultured in D-MEM/F-12 (1:1) with $10 \%$ FBS and 1\% Penicillin/Streptomycin (10,000 U/ml Penicillin, $\quad 10,000 \mu \mathrm{g} / \mathrm{ml} \quad$ Streptomycin; HyClone, SH30023, CH30160, and SV30010, respectively; Logan, UT, USA) at $28^{\circ} \mathrm{C}$.

Three different experimental designs were used for qRT-PCR analyses; each group contained two biological replicates. Treatment groups at each time point were compared with their time-specific control groups $(10 \%$ FBS). Accordingly, (1) dose-dependent serum starvation experiments were performed using $3 \times 10^{6} \mathrm{ZF} 4$ cells (passage number, 13) in T75 flasks incubated with $10 \%$ FBS for $24 \mathrm{~h}$ followed by the addition of media containing a dose series of FBS (i.e., 0, 1, 3 and 10\%) for another $24 \mathrm{~h}$. (2) For the $24 \mathrm{~h}$ serum replenishment experiments, $3.75 \times 10^{6} \mathrm{ZF} 4$ cells (passage number, 16) in T150 flasks were incubated for $24 \mathrm{~h}$ (i.e., time 0 ) and $48 \mathrm{~h}$ with 0.1 or $10 \%$ FBS-containing media after an initial seeding period of $24 \mathrm{~h}$; the $24 \mathrm{~h}$ serum-starved cells were re-incubated with $10 \%$ FBS for another $24 \mathrm{~h}$ (serum replenishment). (3) Similarly, for the $6 \mathrm{~h}$ serum replenishment experiments, 3 $\times 10^{6} \mathrm{ZF} 4$ cells (passage number, 20) were incubated in T75 flasks for $24 \mathrm{~h}$ with media containing $0.1 \% \mathrm{FBS}$ and then re-incubated with 0.1 or $10 \%$ FBS for $6 \mathrm{~h}$. A $30 \mathrm{~h}$ $10 \%$ FBS control group also was included. Cells were counted following trypsin (without EDTA; HyClone, SV30037, Logan, UT, USA) treatment and cell pellets were preserved in liquid nitrogen until later use.
MTT analyses were performed at different serum levels, with $2 \times 10^{4} \mathrm{ZF} 4$ cells (passage number, 22) cultured in triplicates for $24 \mathrm{~h}$ in 96-well microplates. Similarly MTT assays for serum replenishment were performed with $2 \times 10^{4} \mathrm{ZF} 4$ cells (passage number, 19) that were starved for $24 \mathrm{~h}$ in 96-well plates before replenishment with $10 \%$ FBS for the indicated time points. For PI staining, $3 \times 10^{6}$ ZF4 cells (passage numbers, 20-23) were seeded in $100 \mathrm{~mm}$ petri dishes and cultured in 0.1 or $10 \%$ FBS supplemented media. All samples were prepared in duplicates for testing significance. For BrdU analysis $5 \times 10^{5}$ ZF4 cells (passage number, 22) were cultured in 6-well plates in triplicates and serum starved in $0.1 \%$ FBS for $48 \mathrm{~h}$. Effects of $24 \mathrm{~h}$ serum replenishment also were tested.

Assays for cell cycle, viability and proliferation

3-(4,5-dimethylthiazole-2-yl)-2,5-diphenyltetrazolium bromide (MTT), reduced to an insoluble formazan dye by mitochondrial enzymes, provides a reliable cellular assay for detecting viable cells. The MTT assay was performed according to the manufacturer's protocols (Vybrant MTT Cell Proliferation Assay Kit, Molecular Probes, V-13154, Germany). The absorbancy at $540 \mathrm{~nm}$ was read with a $\mu$ Quant $^{\mathrm{TM}}$ Microplate Spectrophotometer (BioTek, Winooski, VT, USA). The results from triplicate measurements were normalized to the blanks and averaged.

The cell cycle analysis of 24-48 h serum-starved or that of $24 \mathrm{~h}$ starved and then replenished ZF4 cells was performed with propidium iodide (PI) staining to assess the percentages of cells at each cell cycle stage [37, 38]. The PI staining was performed as previously described [39]. At each sampling, $3 \times 10^{4}$ cells were analyzed by Becton Dickinson FACScalibur (USA).

The effect of serum starvation on cell proliferation was investigated with 5-bromo-2-deoxyuridine (BrdU) staining as previously described [39]. Briefly, cells were incubated with BrdU adjusted to a final concentration of $0.92 \mu \mathrm{g} / \mathrm{ml}$ for 24 h (Sigma, B9285, St. Louis, MO, USA). Fixed cells were blocked in $10 \%$ FBS in PBS for $1 \mathrm{~h}$ before incubation with an $\alpha$-BrdU antibody (1:500 in 2\% FBS in PBS; Dako, M0744, Denmark) and $\alpha$-mouse secondary antibody (1:750 
in $2 \%$ FBS; Invitrogen, A11029, USA). DAPI was used for counterstaining nuclei. The number of BrdU incorporated cell nuclei was determined by counting multiple fields per group (i.e., approximately 1100-1500 DAPI stained nuclei) on digital fluorescent microscopy images (Zeiss, AX10 Imager A1, Germany).

\section{Real-time qRT-PCR analysis}

Total RNA was isolated from 0, 1, 3 and 10\% FBS-treated samples as well as those from the serum replenishment experiments $(0.1$ and $10 \%$ FBS samples at $6,24,30$ and $48 \mathrm{~h}$ ) using SV total RNA isolation kit (Promega, Z3100, Madison, WI, USA). Reverse-transcription into cDNA was performed by RevertAid First Strand cDNA synthesis kit (Fermentas, K1622, Lithuania). Real-time qRT-PCR analysis was conducted with iCycler (Bio-Rad, Hercules, CA, USA) thermocycler using DyNAmo HS SYBR-green kit (Finnzymes, F-410L, Espoo, Finland). Each cDNA sample was amplified in duplicate by using $20 \mu \mathrm{M}$ gene-specific primers (Table 1). Amplification conditions were $10 \mathrm{~min}$ at $95^{\circ} \mathrm{C}$ followed by 45 cycles of $30 \mathrm{~s}$ at $95^{\circ} \mathrm{C}, 30 \mathrm{~s}$ at $62^{\circ} \mathrm{C}$ (for tyms, $m c m 7$ and $m y b l 2$ ) or $60^{\circ} \mathrm{C}$ (for ctgf, pcna and efla). The primer efficiencies (E) were calculated using 10fold serial dilutions of cDNA where $E$ equals to $10^{[-1 / \text { slope }}$ of the dilution curve] (Table 1). The relative expression ratio of target genes were calculated using a modified delta-delta $\mathrm{Ct}$ method [40] based on primer pair-specific amplification efficiencies and efla as the reference gene [41, 42]. The $\log 2$ transformed fold change values were plotted in the figures and were used for testing significant differences. For each gene, the real-time qRT-PCR reactions were performed in the same run using biological and technical duplicates.

\section{Western blot}

Western blots were performed in order to analyze the serum response of the Mcm7 protein expression. Briefly, cells were lysed with NP-40 lysis buffer containing $50 \mathrm{mM}$ Tris- $\mathrm{HCl}, \mathrm{pH} 8,150 \mathrm{mM} \mathrm{NaCl}, 1 \% \mathrm{NP} 40$ and $1 \mathrm{X}$ protease inhibitor complex (Roche, Mannheim, Germany). Protein quantification was performed using Bradford solution (Sigma, B6916, St. Louis, MO, USA). $20 \mu \mathrm{g}$ of total protein lysate was subjected to gel electrophoresis and transferred (Invitrogen, Carlsbad, USA) as previously described [39]. Western blotting was performed using the primary antibodies, Mcm7 (Santa Cruz Biotechnology, sc9966, Santa Cruz, CA, USA) or $\alpha$-Tubulin (Calbiochem, CP06, Darmstadt, Germany), following $1 \mathrm{~h}$ incubation with the horseradish peroxidase (HRP)-conjugated goat anti-mouse secondary antibody (Sigma, St. Louis, MO, USA). Proteins were detected using ECLplus (Amersham, rpn 2132,
Buckinghamshire, UK). Mcm7 protein expression was compared against that of $\alpha$-Tubulin for the same set of samples.

\section{Statistical analyses}

The MTT, BrdU and PI staining results were analyzed by One-way ANOVAs to test for the dose dependency and/or effects of serum replenishment in response to serum in ZF4 cells. The $\log 2$ transformed real-time qRT-PCR expression results for dose-dependent serum starvation for tyms, mybl2, pcna, ctgf, and $m c m 7$ and were compared among groups using a One-way ANOVA. The time-dependent serum replenishment data for the same genes were analyzed using a Two-way ANOVA to test for effects of time and dose, simultaneously. For both the starvation and replenishment experiments, pairwise analyses between dose treatments within an ortholog were then performed using Fisher's pairwise comparisons following use of a One-way ANOVA. All analyses were performed in Minitab ${ }^{\circledR}$ and plotted with GraphPad Prism ${ }^{\circledR} 5.0$ (USA).

\section{Results}

Phylogenetic conservation of PCNA, MYBL2, TYMS, MCM7, and CTGF

Phylogenetic analyses of selected genes showed variable degrees of conservation of the zebrafish homologs with their vertebrate orthologs, yet expectedly the mammalian proteins clustered together while the zebrafish orthologs were closer to fish counterparts (Fig. 1a-e).

The zebrafish and mammalian comparisons based on ClustalW indicated that the sequence similarity ranged from low to high depending on the gene under consideration. For example, the zebrafish Mybl2 amino acid sequence was very weakly conserved among taxa (53\% between human and zebrafish) whereas Pcna protein sequence identity among species was relatively higher ( $90 \%$ between human and zebrafish). The Tyms, Ctgf and $\mathrm{Mcm} 7$ protein sequence similarities between human and zebrafish ranged between 75 and $80 \%$ (Table S2).

Analysis of cell cycle and proliferation in serumstarved/replenished ZF4 cells

The cell cycle analysis of 24-48 h serum-starved ZF4 cells was performed with PI staining. Our results revealed that a large fraction of the control ZF4 cells were found at the G0/ G1 phase of the cell cycle (Fig. 2). However, serum starvation caused a significant increase in cells at the G0/G1 phase, while decreasing the number of cells entering the $S$ 
Fig. 1 The phylogenetic analyses of selected E2F target ortholog protein sequences in different species (Table S1). a Ctgf; b Mybl2; c Tyms; d Mcm7; e Pcna. The bootstrapped neighbor-joining phylogenetic tree was generated using MEGA4. Species: Human $(H s)$, rat $(R n)$, mouse $(M m)$, chicken $(G g)$, western clawed frog $(X t)$, zebrafish $(D r)$, fugu $(\operatorname{Tr})$, medaka $(O l)$, cow $(B t)$, salmon $(S s)$, stickleback $(G a)$, green spotted puffer fish $(T n)$. Scale bar refers to substitutions per site
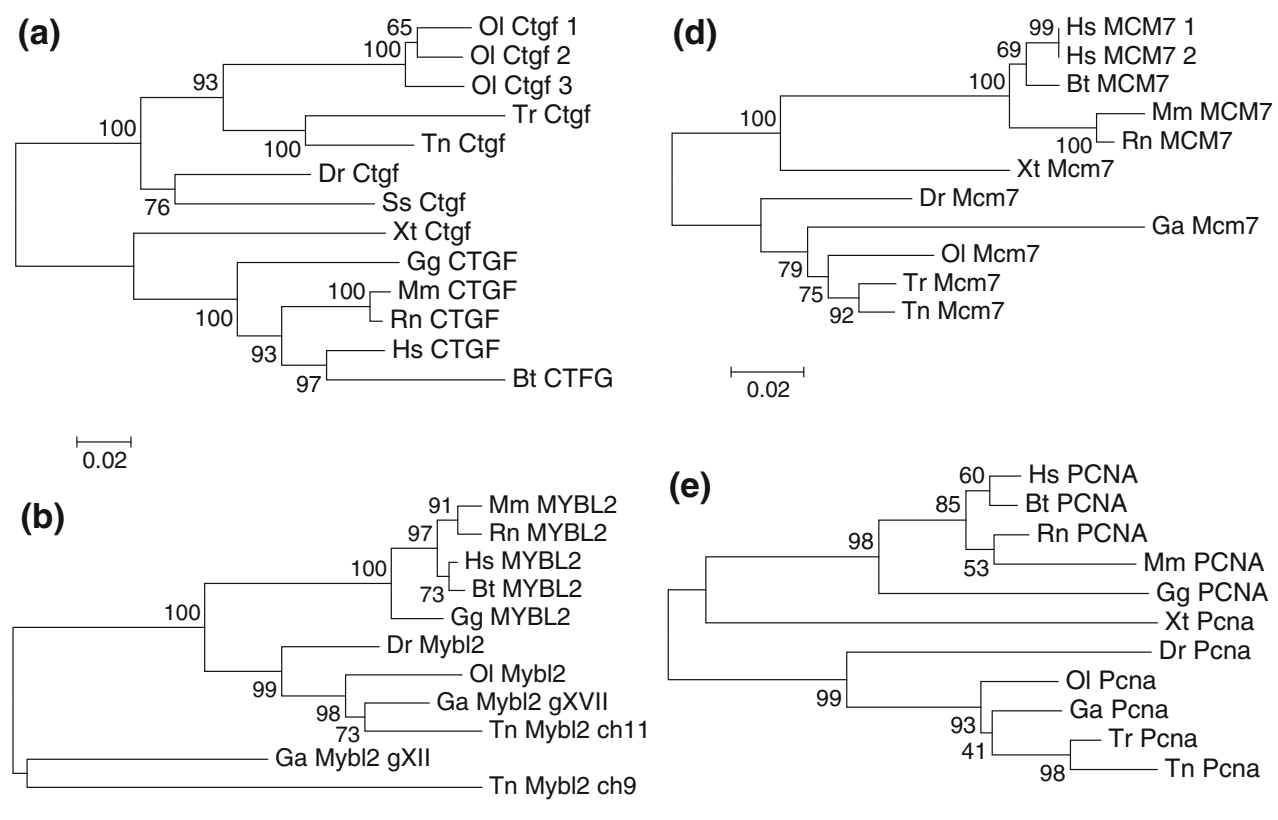

0.05

(c)

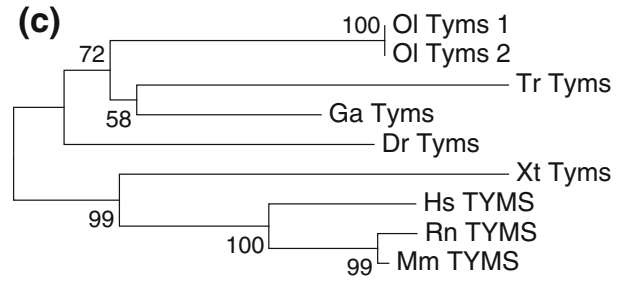

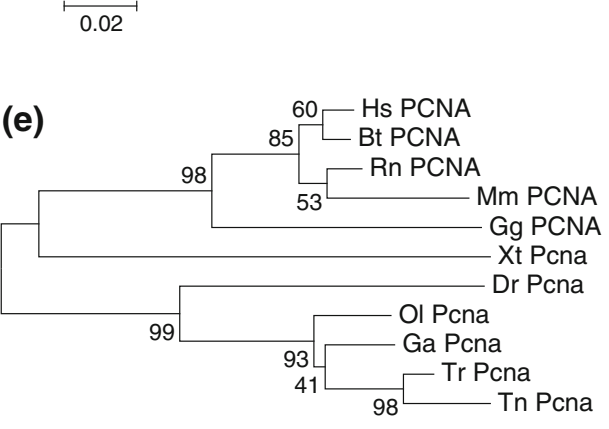

0.01

0.02

and to a lesser degree the G2/M phases for both the 24 and $48 \mathrm{~h}$ serum starvation experiments. The treatment with serum for $24 \mathrm{~h}$ increased the number of cells entering the $\mathrm{S}$ phase, when compared with the serum-starved and nonstarved cells; this increase might have reflected a synchronization event induced by serum starvation for cells at the G1 phase of the cell cycle (Fig. 2). When cells were cultured at a lower confluency, a similar trend was observed such that serum starvation resulted in an increase in $\mathrm{G0} / \mathrm{G} 1$ and a decrease in S phases (Fig. S1). However, our findings suggest that the number of $10 \%$ FBS-treated cells at G0/G1 might be influenced by the level of confluency while the serum-starved cell numbers did not vary with confluency levels (Fig. 2 vs. Fig. S1).

Our results also showed that serum starvation caused a significant decrease in cell proliferation such that the rate of BrdU incorporation was $99 \%$ in the control ZF4 cells cultured with $10 \%$ FBS for $48 \mathrm{~h}$, while only $11 \%$ of the cells incorporated BrdU upon $48 \mathrm{~h}$ serum starvation (Fig. 3). The ZF4 cells that were serum-starved and then replenished for $24 \mathrm{~h}$ reentered a state of proliferation. This indicated that the effect of $24 \mathrm{~h}$ serum starvation on DNA synthesis was reversible.
Dose-dependent response to serum starvation

The increase in cell viability of ZF4 cells was directly correlated with the increased serum levels. The pairwise comparisons showed that the 0,1 and 3\% FBS groups responded to reduced serum levels by a significant decrease in cell viability (Fig. 4a, One-way ANOVA; $P \leq 0.001$ for $\%$ FBS).

One-way ANOVA performed on real-time qRT-PCR results showed that mybl2, $m \mathrm{~cm} 7$ and tyms expression levels decreased significantly under serum starvation in a dose-dependent manner while the level of change approached significance in pcna (Fig. 4b). Pairwise tests based on Fisher's multiple comparisons indicated that the expressions of mybl2, mcm 7 , tyms and pcna genes were significantly down regulated at the $0 \%$ FBS treatment but only for $m y b l 2$ and $m c m 7$, the change in expression was significant also at the $1 \%$ FBS level when compared to control levels. ctgf showed a significant dose-dependent response to serum starvation; ctgf expression steadily increased at the 3 and 1\% FBS treatments, while there was no significant difference between the 10 and $0 \%$ FBS treatments (Fig. 4b). 
Fig. 2 Cell cycle analysis of ZF4 cells in response to serum fluctuations. The mean percentage of cells at the $\mathrm{G} 0$ / $\mathrm{G} 1, \mathrm{~S}, \mathrm{G} 2 / \mathrm{M}$ for the $24 \mathrm{~h}$ and $48 \mathrm{~h}$ serum starvation and $24 \mathrm{~h}$ serum replenishment $(24 \mathrm{~h}$ $0.1 \%$ FBS following $24 \mathrm{~h} 10 \%$ FBS) experiments were shown along with \pm standard deviation. *indicates a significant difference from the 10\% FBS group while \# refers to a significant difference between the $48 \mathrm{~h} 0.1 \%$ FBS and $24 \mathrm{~h}$ replenishment groups at $P \leq 0.05$
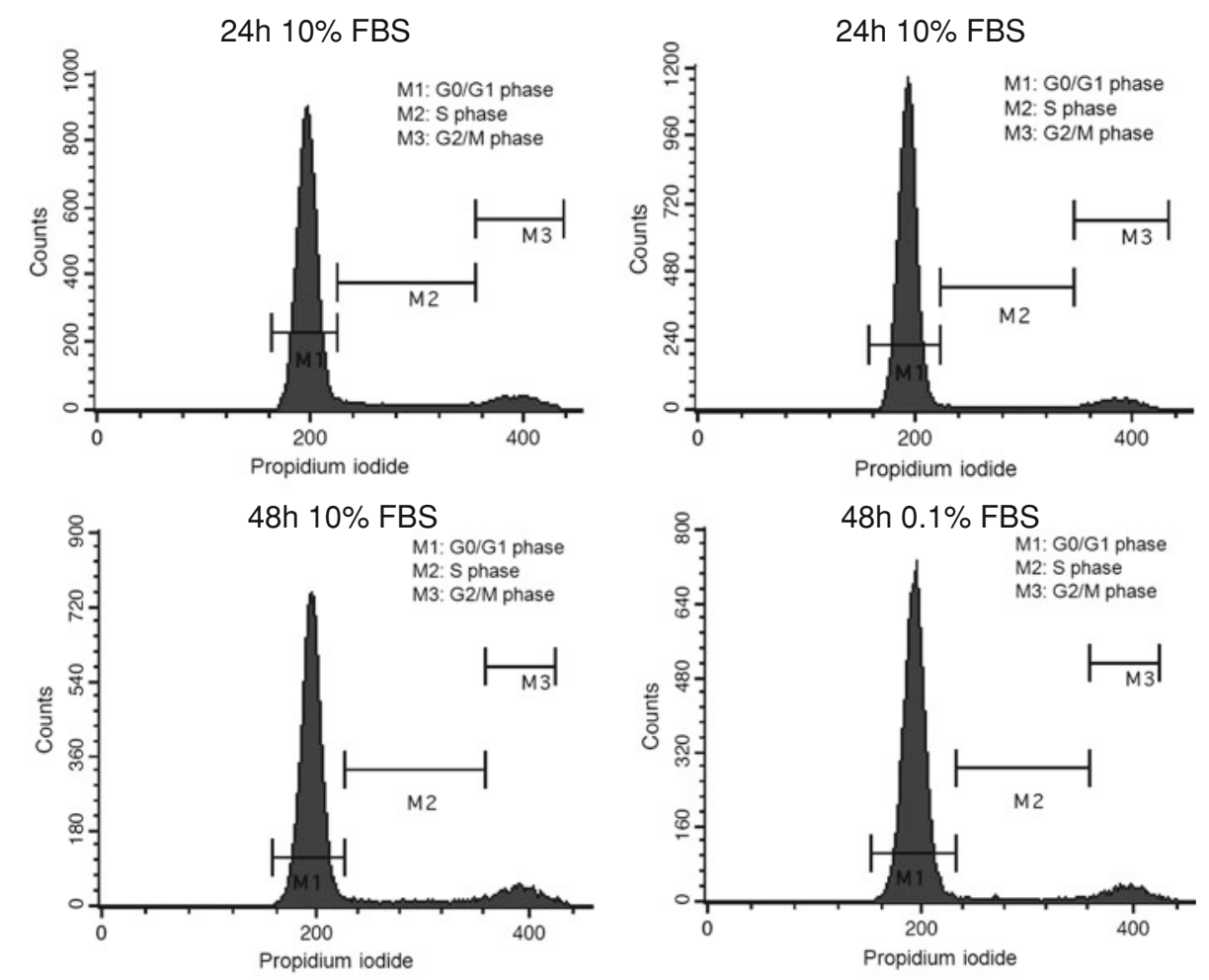

\begin{tabular}{|c|c|c|c|c|c|}
\hline & $\begin{array}{c}24 \mathrm{~h} \\
10 \% \mathrm{FBS}\end{array}$ & $\begin{array}{c}24 \mathrm{~h} \\
0.1 \% \mathrm{FBS}\end{array}$ & $\begin{array}{c}48 \mathrm{~h} \\
10 \% \mathrm{FBS}\end{array}$ & $\begin{array}{c}48 \mathrm{~h} \\
0.1 \% \text { FBS }\end{array}$ & $\begin{array}{c}24 \mathrm{~h} \\
\text { Replenishment }\end{array}$ \\
\hline$\overline{\mathrm{G} 0 / \mathrm{G} 1}$ & $85.40 \pm 0.12$ & $91.48 \pm 0.26^{*}$ & $85.24 \pm 0.86$ & $91.22 \pm 0.02 *$ & $80.66 \pm 0.28^{\# *}$ \\
\hline S & $6.44 \pm 0.60$ & $2.25 \pm 0.05 *$ & $5.90 \pm 0.28$ & $2.32 \pm 0.42 *$ & $8.27 \pm 0.24^{\# *}$ \\
\hline $\mathrm{G} 2 / \mathrm{M}$ & $8.35 \pm 0.49$ & $6.35 \pm 0.21 *$ & $8.75 \pm 1.04$ & $6.28 \pm 0.45$ & $11.25 \pm 0.11^{\#}$ \\
\hline
\end{tabular}

Time-dependent response to serum replenishment

Serum replenishment for $6 \mathrm{~h}$ was adequate for recovery of the cells from reduced cell viability caused by serum starvation (Fig. 5a, One-way ANOVA; $P \leq 0.001$ ), while the $24 \mathrm{~h}$ serum replenishment allowed for complete recovery of cell viability (Fig. 5b, One-way ANOVA; $P \leq 0.001$ ).

The expressions of tyms, mybl2, mcm 7 and pcna were significantly different in at least one of the groups tested (i.e., 24 or 48 h serum-starved ( $0.1 \%$ FBS) or control (10\% FBS) groups). A Two-way ANOVA showed that the starvation associated decrease observed in the expression of these genes was significant and independent of time (Fig. 6a, Two-way ANOVA according to $\log 2$ transformed fold change difference; tyms, $P_{\text {dose }}=0.001, P_{\text {time }}=0.558 ;$ mybl $2, P_{\text {dose }} \leq$ $0.001, P_{\text {time }}=0.212$; pcna $, P_{\text {dose }}=0.001, P_{\text {time }}=0.276$; $\left.m c m 7, P_{\text {dose }} \leq 0.001, P_{\text {time }}=0.576\right)$. Serum-starved cells at both the 24 and $48 \mathrm{~h}$ showed significant decreases in the mRNA levels of mybl2, mcm 7 and pcna whereas that of tyms was only significantly different from the $24 \mathrm{~h} 10 \%$ FBS 
Fig. 3 BrdU incorporation in serum-starved/replenished ZF4 cells. ZF4 cells treated with $0.1 \%$ FBS for $48 \mathrm{~h}$ were compared with those in control group cultured in $10 \%$ FBS for $48 \mathrm{~h}$. In the replenishment group, cells recovered from starvation for $24 \mathrm{~h}$ ( $24 \mathrm{~h}$ rep.). Nuclei were stained by DAPI where BrdU incorporating cell nuclei were observed using the green filter. Scale bars

represented a distance of $20 \mu \mathrm{m}$ and the magnification was set at $\times 40$. The mean number of BrdU positive nuclei corrected against the total number of nuclei per group was plotted, whiskers correspond to \pm std. *indicates significance at $P \leq 0.05$
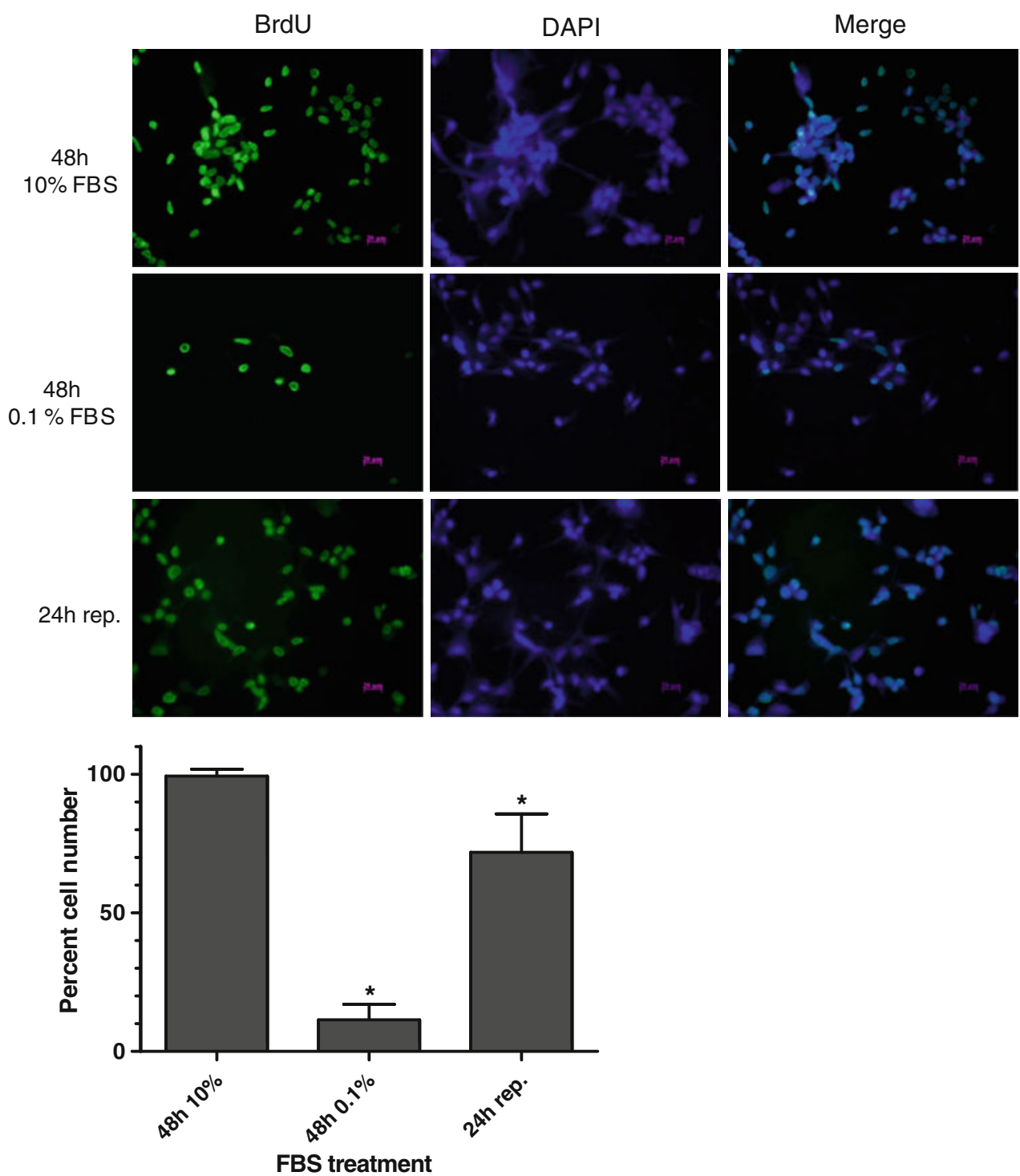

treatment. Strikingly, the serum replenishment restored expression to the original levels (Fig. 6a). The transcriptional change in ctgf, on the other hand, was time-dependent, yet highly significant at both the 24 and $48 \mathrm{~h}$ time-points (Fig. 6a, Two-way ANOVA according to $\log 2$ transformed fold change difference; $\operatorname{ctg} f, P_{\text {dose }} \leq 0.001, P_{\text {time }}=0.01$ ). The level of protein expression of Mcm7 also exhibited a significant decrease under the $24 \mathrm{~h}$ serum starvation regime (Fig. 6b) suggesting that changes observed at the mRNA levels also were reflected in the protein synthesis.

We also quantitatively analyzed the change in mRNA levels for cells replenished with 10\% FBS for $6 \mathrm{~h}$ upon serum starvation (Fig. 7a). The expression levels of tyms, $m y b l 2$ and pcna increased significantly with serum at $6 \mathrm{~h}$ as they did at $24 \mathrm{~h}$, while the expression of $\operatorname{ctg} f$ was unaffected. The change in $m c m 7$ mRNA expression approached significance at $6 \mathrm{~h}$ while it was highly significant at $24 \mathrm{~h}$. $\mathrm{mcm} 7$ gene expression was also studied at the protein level. There was a consistent decrease in the $\mathrm{Mcm} 7$ protein levels by serum starvation at the 24 and $48 \mathrm{~h}$ treatments. The serum replenishment, particularly for the $24 \mathrm{~h}$, was highly effective in restoring the original level of protein expression for Mcm7 (Fig. 7b).

\section{Discussion}

In the present study, we investigated the expression patterns of the zebrafish orthologs of the known mammalian direct or secondary targets of E2F transcription factors; tyms, mybl2, pcna, ctgf and mcm7 in serum-starved/ replenished ZF4 cells using real-time qRT-PCR analyses. Moreover, we demonstrated for the first time that in ZF4 cells serum starvation and replenishment treatments 
Fig. 4 Dose-dependency of ZF4 serum response a MTT assay results of $\mathrm{ZF} 4$ grown under different serum concentrations, i.e., $0,1,3$ or $10 \%$ FBS-supplemented media, for $24 \mathrm{~h}$, b The real-time qRTPCR results of selected genes in response to serum starvation.

The ZF4 cells were grown in 0 , 1,3 or $10 \%$ FBS-supplemented media for $24 \mathrm{~h}$. Data were normalized to the $10 \%$ FBS treatment. (One-way ANOVA according to $\log 2$ transformed fold change difference; tyms, $P=0.024 ;$ mybl2,$P \leq 0.001$; pcna, $P=0.077$; ctgf,

$P=0.013 ; \mathrm{mcm} 7, P=0.001)$.

$\mathrm{a}, \mathrm{b}, \mathrm{c}$ refers to significance at $P \leq 0.05$ from 10,3 , and $1 \%$

FBS, respectively, based on

Fisher's multiple comparisons (a)

MTT
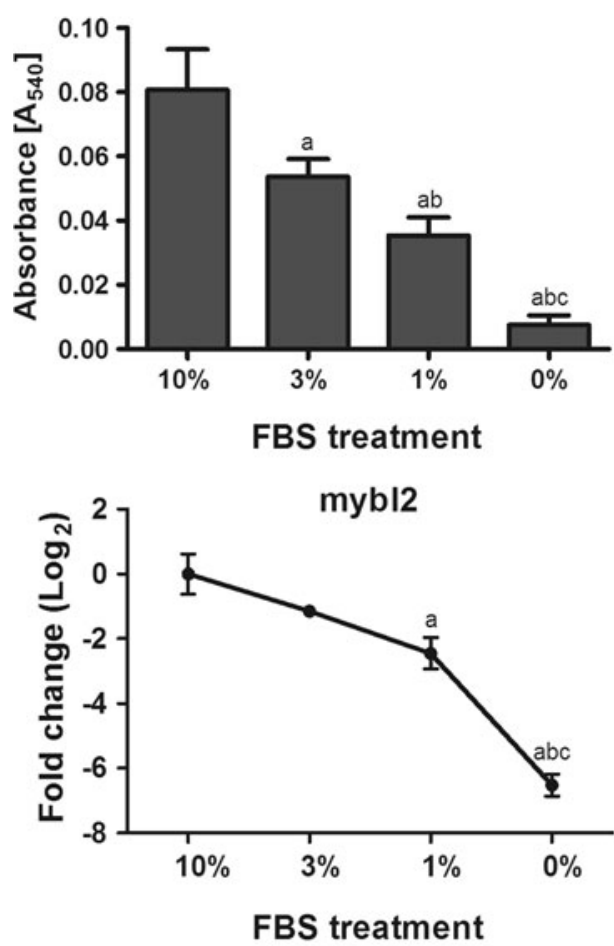

pcna

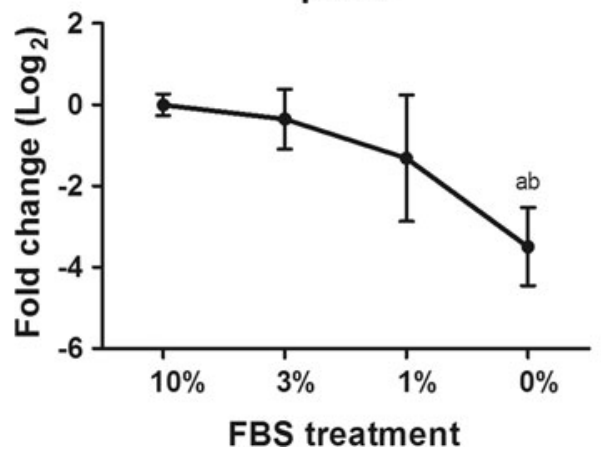

(a)

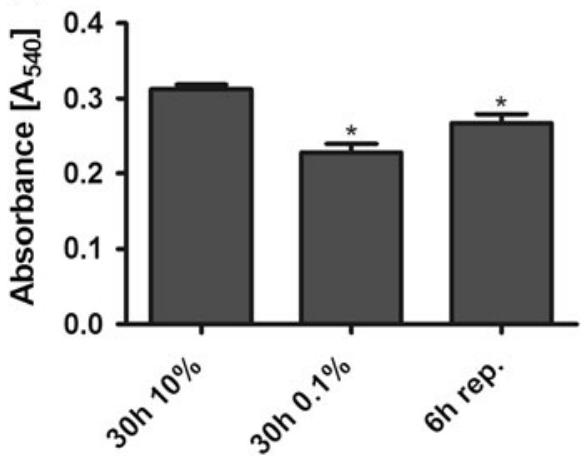

FBS treatment (b) tyms
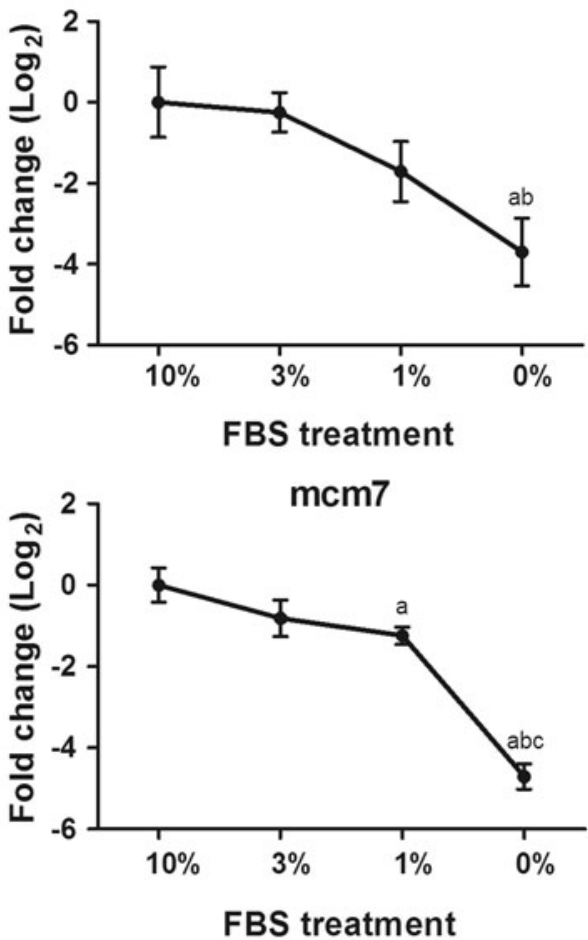

ctgf

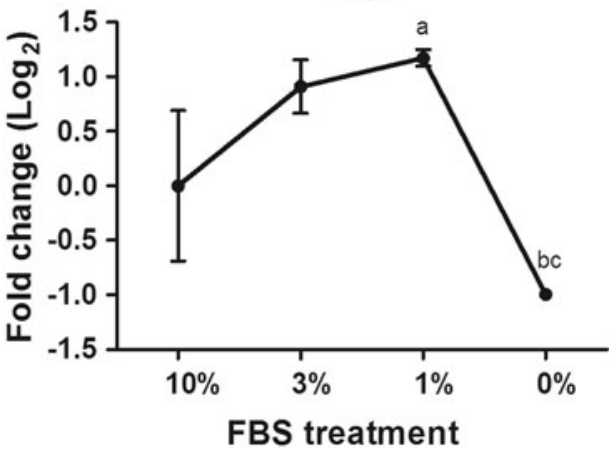

(b)

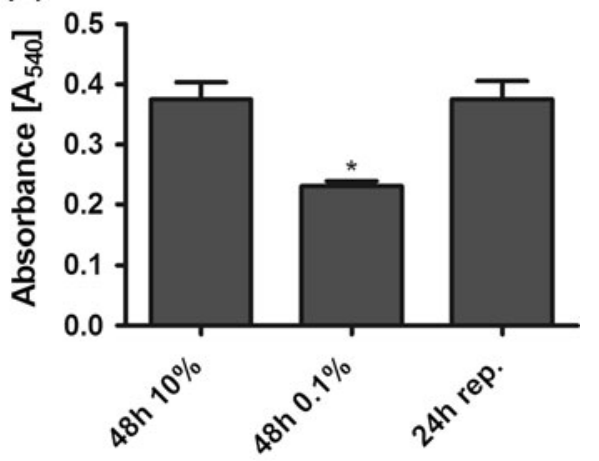

FBS treatment significantly affected cells at different cell cycle phases in ZF4 cells. In the literature, there are a few examples showing that the serum response might be dose- and time- dependent [20, 43-46]. Herein we showed that the effects of serum starvation/replenishment on gene expression of E2F target orthologs were dose- and time-dependent in 
Fig. 6 a The real-time qRTPCR results of selected genes under $24 \mathrm{~h}$ serum replenishment regime. The real-time qRT-PCR results were normalized to the 24 h $10 \%$ FBS-treatment. Oneway ANOVA results were, for 24 h: tyms, $P=0.002 ;$ mybl2, $P=0.031$; pcna, $P=0.013$, ctgf, $P=0.028 ; \mathrm{mcm} 7$, $P=0.015$ for $48 \mathrm{~h}$ : tyms, $P=0.03$; mybl2, $P \leq 0.001$; pcna, $P=0.005$; ctgf, $P=0.007 ; \mathrm{mcm} 7, P \leq 0.001$.

$*$ refers to a group significantly different from the $10 \%$ control at the given time point. $10 \%$ rep. refers to the treatment of $24 \mathrm{~h}$ serum starvation followed by $24 \mathrm{~h}$ serum replenishment. b Protein expression of $\mathrm{Mcm} 7$ gene for the $24 \mathrm{~h}$ starved versus asynchronized ZF4 cells (a)

tyms
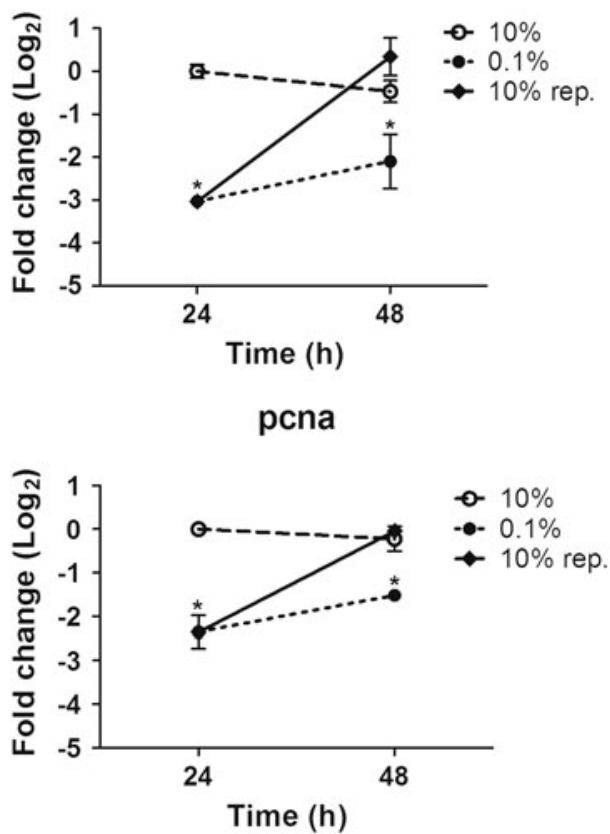

$\mathrm{mcm} 7$

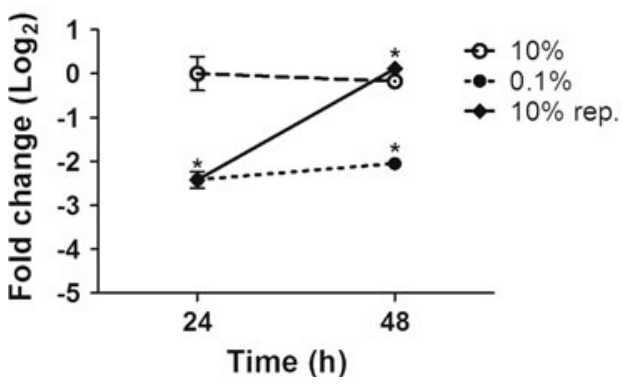

mybl2
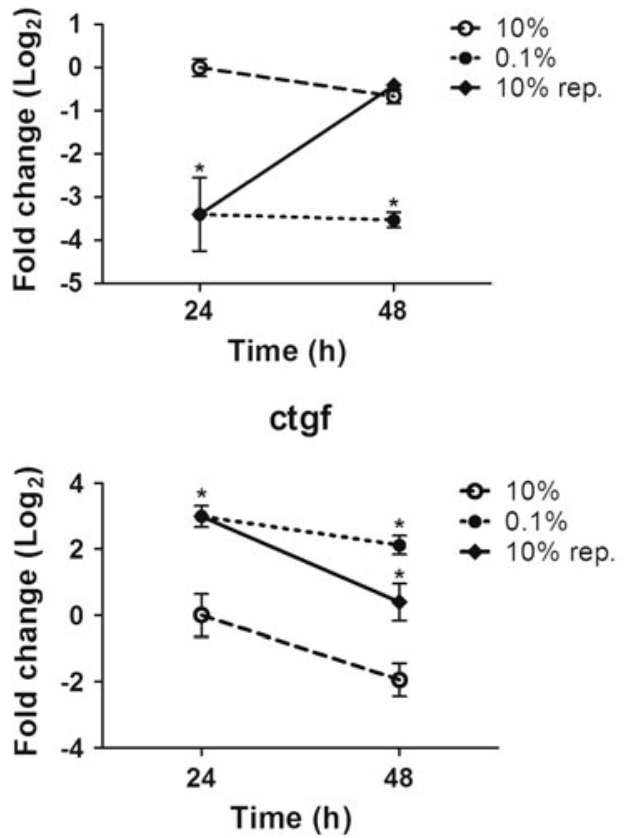

(b)

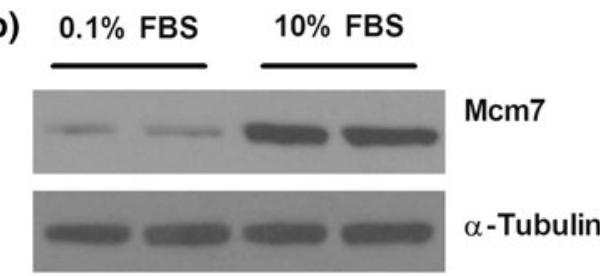

ZF4 cells. In the present study, ZF4 cells arrested at G0/G1 upon serum starvation served as a model for quiescence. The transcriptional serum responses of the selected genes were in accord with findings from studies performed with mammalian cells.

The characterization of proliferative properties of ZF4 cells in response to serum

The asynchronized mammalian fibroblasts accumulate in G0/G1 phase of the cell cycle after serum starvation and reenter the S phase upon serum stimulation [47]. Herein, we described the cellular serum response of the ZF4 fibroblast cell line, a frequently used in vitro model in zebrafish [48-52]. Our results showed that (a) the serum starvation significantly decreased the viable cell numbers, which were later on rescued by serum replenishment; and (b) the viable ZF4 cells that have survived the serum starvation stopped proliferating and became arrested at the G0/G1 phase of cell cycle as previously shown in the mammalian fibroblast cells [47, 53-56]. Most strikingly, the serum-replenished cells reentered the $\mathrm{S}$ phase of cell cycle and commenced proliferation as the mammalian fibroblasts [57]. The high percentage of ZF4 cells entering the $S$ phase after serum stimulation represented a likely synchronization process caused by serum starvation.

The expression response to serum fluctuations in ZF4 cells in comparison to that in mammals

Recent studies emphasize the role of comparative models in understanding the functional conservation of important cell signaling components. Our findings indicated that the zebrafish pcna, tyms, mcm 7 and mybl2 genes were highly responsive to serum in the direction observed in mammalian cells $[18,20,21]$.

The real-time qRT-PCR results showed that the zebrafish pcna expression was highly responsive to serum starvation and replenishment as previously shown for mouse embryonic fibroblast (MEF) $[21,58]$ and in the Chinese 
Fig. 7 a The real-time qRTPCR results for $6 \mathrm{~h}$ serumreplenished cells. The real-time qRT-PCR results were normalized to the $30 \mathrm{~h} 10 \%$ FBS-treatment. One-way ANOVA results were: tyms, $P=0.011 ; m y b l 2, P=0.001$; pcna, $P=0.014$; ctgf, $P=0.053 ; \mathrm{mcm} 7, P=0.095$. The significance at $P \leq 0.05$ was represented as $* \mathbf{b}$ Protein expression of $\mathrm{Mcm} 7$ under serum starvation and replenishment (a)

tyms

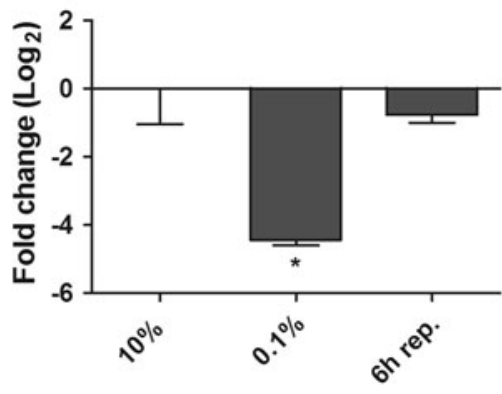

FBS treatment

pcna

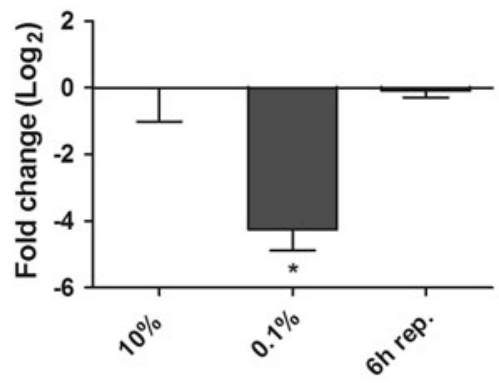

FBS treatment

$\mathrm{mcm} 7$

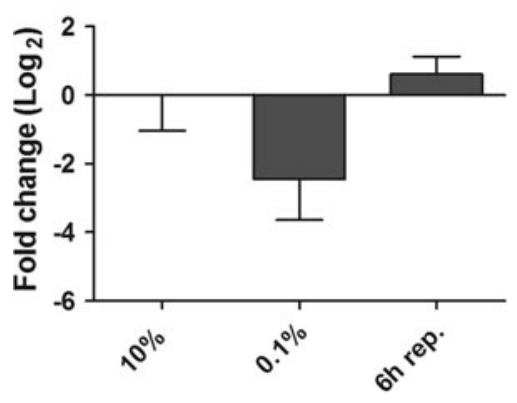

mybl2

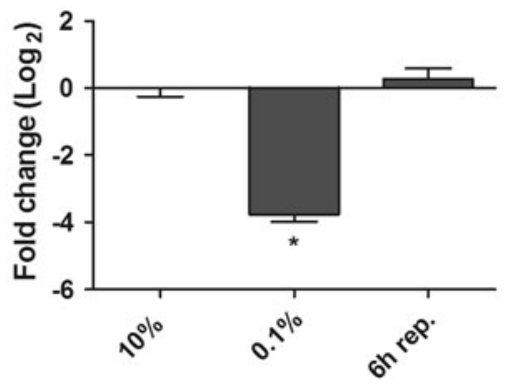

FBS treatment

ctgf

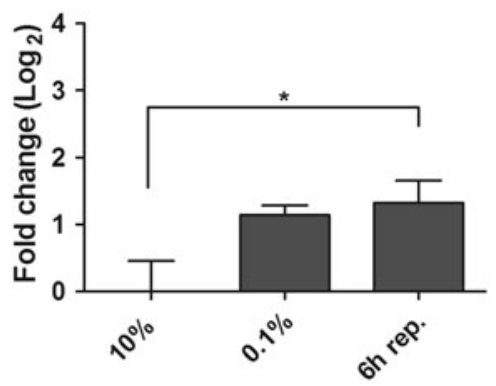

FBS treatment

(b)

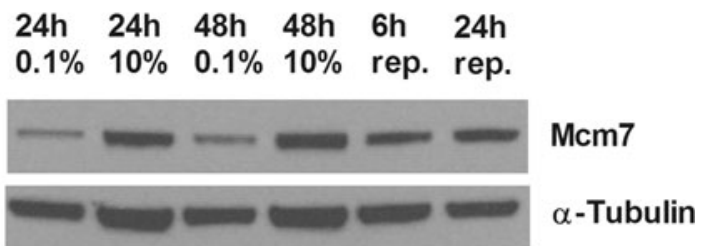

FBS treatment

hamster ovary cell line (CHOK1) [59]. Serum starvation resulted in a highly significant decrease in the expression of the zebrafish mybl2 in our study as in the normal human bone marrow fibroblasts [19]. We observed an increase in mybl2 expression starting from $6 \mathrm{~h}$ of serum stimulation. In quiescent mouse embryonic fibroblast cells the Mybl2 mRNA increased gradually after serum stimulation starting at the $12 \mathrm{~h}$ of serum replenishment [60].

We detected a significant increase in the tyms expression even within $6 \mathrm{~h}$ of serum replenishment. A similar increase in the Tyms expression following serum stimulation also was observed in NIH 3T3 cells between the $8 \mathrm{~h}-10 \mathrm{~h}$ of serum treatment [61] yet in mouse 3T6 fibroblasts, the Tyms activity showed a decrease under long-term serum starvation [31].
We have found that $\operatorname{ctg} f$ expression was serum-responsive in a time-dependent manner and most drastically increased at the $24 \mathrm{~h} 0.1 \%$ FBS treatment; the expression was reduced following serum recovery between the 6-24 h. Human $C T G F$ expression also responded to serum in the same direction based on the GEO microarray expression profile analysis of human T98G cells [11]. Stimulatory effects of serum starvation on zebrafish ctgf thus suggest significant functional conservation across vertebrate taxa. However, the direction of the effects might be species as well as cell-type specific, as in contrast to our findings, a decrease in the $C T G F$ mRNA was detected after serum stimulation in a human mesangial cell line [22].

In mouse and human cells, the prolonged quiescent state caused the downregulation of all the $\mathrm{mcm}$ proteins 
(MCM2-7), while reentering into the G1 phase led to upregulation of $\mathrm{Mcm}$ transcripts and proteins [18]. We have shown that $m c m 7$ expression in ZF4 cells was serumresponsive, while the changes observed at the mRNA levels were linearly reflected at the protein level; similar changes were observed in the serum-stimulated MCF7 breast cancer cells [62]. The mRNA and protein expression of the $m \mathrm{~cm} 7$ gene have been characterized in zebrafish model for the first time in the present study. However, to better assess the correlation between mRNA and protein levels under serum starvation, further studies focusing on other genes are needed.

In conclusion, our findings indicated that the level of serum incorporated into the media has been reflected in the cellular characteristics as well as the transcriptional response the ZF4 cells displayed, suggesting a significant dose- and time-dependency in serum response. Furthermore, we showed that the fibroblast serum response in zebrafish was highly similar to that in mammals with respect to the genes under investigation. Serum starvation was as effective at the 48th $\mathrm{h}$ as at the 24th $\mathrm{h}$ for pcna, tyms, mcm7, mybl2, and ctgf. $6 \mathrm{~h}$ serum replenishment experiments on the other hand showed that only the expression of tyms, mybl2 and pcna returned to near normal levels while the $m c m 7$ and $c t g f$ responded to increased serum levels relatively later. Moreover, the mammalian orthologs of the selected genes examined in the present study are known to be regulated by different transcription factors in addition to E2F family members, i.e., c-myc, p53, and/or TFG- $\beta 2$ [16, 63-68]. It will be interesting to further test whether these zebrafish orthologs also share common transcriptional regulatory signatures.

Acknowledgments This study was supported by research Grants from TUBITAK, The Scientific and Technological Research Council of Turkey (to MO and OK). This project partially contributes to the fulfillment of requirements for the PhD thesis of Ceren Sucularli. We thank to Dr. Ali O. Gure, Ms. Rana Nelson and Dr. Michelle Adams for valuable suggestions in reviewing the manuscript. We also kindly thank Gizem Olmezer for her help in protein preparation for western blot analysis.

\section{References}

1. Lam SH, Wu YL, Vega VB, Miller LD, Spitsbergen J et al (2006) Conservation of gene expression signatures between zebrafish and human liver tumors and tumor progression. Nat Biotechnol 24:73-75

2. Linhart C, Elkon R, Shiloh Y, Shamir R (2005) Deciphering transcriptional regulatory elements that encode specific cell cycle phasing by comparative genomics analysis. Cell Cycle 4:1788-1797

3. Ung CY, Lam SH, Gong Z (2009) Comparative transcriptome analyses revealed conserved biological and transcription factor target modules between the zebrafish and human tumors. Zebrafish 6:425-431
4. Feitsma H, Cuppen E (2008) Zebrafish as a cancer model. Mol Cancer Res 6:685-694

5. Stoletov K, Klemke R (2008) Catch of the day: zebrafish as a human cancer model. Oncogene 27:4509-4520

6. Lee LM, Seftor EA, Bonde G, Cornell RA, Hendrix MJ (2005) The fate of human malignant melanoma cells transplanted into zebrafish embryos: assessment of migration and cell division in the absence of tumor formation. Dev Dyn 233:1560-1570

7. Porter D, Weremowicz S, Chin K, Seth P, Keshaviah A, et al. (2003) A neural survival factor is a candidate oncogene in breast cancer. Proceedings of the National Academy of Sciences of the USA 100: 10931-10936

8. Nakashima T, Kuratomi Y, Yasumatsu R, Masuda M, Koike K et al (2005) The effect of cyclin D1 overexpression in human head and neck cancer cells. Eur Arch Otorhinolaryngol 262:379-383

9. Chang HY, Sneddon JB, Alizadeh AA, Sood R, West RB et al (2004) Gene expression signature of fibroblast serum response predicts human cancer progression: similarities between tumors and wounds. PLoS Biol 2:E7

10. He S, Salas-Vidal E, Rueb S, Krens SF, Meijer AH et al (2006) Genetic and transcriptome characterization of model zebrafish cell lines. Zebrafish 3:441-453

11. Cam H, Balciunaite E, Blais A, Spektor A, Scarpulla RC et al (2004) A common set of gene regulatory networks links metabolism and growth inhibition. Mol Cell 16:399-411

12. Dorner D, Vlcek S, Foeger N, Gajewski A, Makolm C et al (2006) Lamina-associated polypeptide 2alpha regulates cell cycle progression and differentiation via the retinoblastoma-E2F pathway. J Cell Biol 173:83-93

13. Weinberg RA (1996) E2F and cell proliferation: a world turned upside down. Cell 85:457-459

14. Johnson DG, Schwarz JK, Cress WD, Nevins JR (1993) Expression of transcription factor E2F1 induces quiescent cells to enter S phase. Nature 365:349-352

15. Kherrouche Z, Blais A, Ferreira E, De Launoit Y, Monte D (2006) ASK-1 (apoptosis signal-regulating kinase 1) is a direct E2F target gene. Biochem J 396:547-556

16. Bracken AP, Ciro M, Cocito A, Helin K (2004) E2F target genes: unraveling the biology. Trends Biochem Sci 29:409-417

17. Arata Y, Fujita M, Ohtani K, Kijima S, Kato JY (2000) Cdk2dependent and -independent pathways in E2F-mediated $S$ phase induction. J Biol Chem 275:6337-6345

18. Stoeber K, Tlsty TD, Happerfield L, Thomas GA, Romanov S et al (2001) DNA replication licensing and human cell proliferation. J Cell Sci 114:2027-2041

19. Scortechini AR, Rupoli S, Piccinini G, Luchetti MM, Cantori I et al (1999) Expression of c-myb and B-myb oncogenes on myelofibrotic marrow fibroblasts. Leuk Lymphoma 33:295-304

20. Le Francois BG, Maroun JA, Birnboim HC (2007) Expression of thymidylate synthase in human cells is an early $\mathrm{G}(1)$ event regulated by CDK4 and p16INK4A but not E2F. Br J Cancer 97:1242-1250

21. Hurford RK Jr, Cobrinik D, Lee MH, Dyson N (1997) pRB and p107/p130 are required for the regulated expression of different sets of E2F responsive genes. Genes Dev 11:1447-1463

22. Goppelt-Struebe M, Hahn A, Iwanciw D, Rehm M, Banas B (2001) Regulation of connective tissue growth factor ( $\operatorname{ccn} 2$; ctgf) gene expression in human mesangial cells: modulation by HMG CoA reductase inhibitors (statins). Mol Pathol 54:176-179

23. Leung AY, Leung JC, Chan LY, Ma ES, Kwan TT et al (2005) Proliferating cell nuclear antigen (PCNA) as a proliferative marker during embryonic and adult zebrafish hematopoiesis. Histochem Cell Biol 124:105-111

24. Dickmeis T, Plessy C, Rastegar S, Aanstad P, Herwig R et al (2004) Expression profiling and comparative genomics identify a 
conserved regulatory region controlling midline expression in the zebrafish embryo. Genome Res 14:228-238

25. Chiou MJ, Chao TT, Wu JL, Kuo CM, Chen JY (2006) The physiological role of $\mathrm{CTGF} / \mathrm{CCN} 2$ in zebrafish notochond development and biological analysis of the proximal promoter region. Biochem Biophys Res Commun 349:750-758

26. Stern HM, Murphey RD, Shepard JL, Amatruda JF, Straub CT et al (2005) Small molecules that delay S phase suppress a zebrafish bmyb mutant. Nat Chem Biol 1:366-370

27. Shepard JL, Amatruda JF, Stern HM, Subramanian A, Finkelstein D, et al. (2005) A zebrafish bmyb mutation causes genome instability and increased cancer susceptibility. Proceedings of the National Academy of Sciences of the USA 102: 13194-13199

28. Ryu S, Holzschuh J, Erhardt S, Ettl AK, Driever W (2005) Depletion of minichromosome maintenance protein 5 in the zebrafish retina causes cell-cycle defect and apoptosis. Proceedings of the National Academy of Sciences of the USA 102: 18467-18472

29. Ryu S, Driever W (2006) Minichromosome maintenance proteins as markers for proliferation zones during embryogenesis. Cell Cycle 5:1140-1142

30. Golling G, Amsterdam A, Sun Z, Antonelli M, Maldonado E et al (2002) Insertional mutagenesis in zebrafish rapidly identifies genes essential for early vertebrate development. Nat Genet $31: 135-140$

31. Navalgund LG, Rossana C, Muench AJ, Johnson LF (1980) Cell cycle regulation of thymidylate synthetase gene expression in cultured mouse fibroblasts. J Biol Chem 255:7386-7390

32. Muller H, Bracken AP, Vernell R, Moroni MC, Christians F et al (2001) E2Fs regulate the expression of genes involved in differentiation, development, proliferation, and apoptosis. Genes Dev 15:267-285

33. Rozen S, Skaletsky H (2000) Primer3 on the WWW for general users and for biologist programmers. Methods Mol Biol 132:365-386

34. Thompson JD, Higgins DG, Gibson TJ (1994) CLUSTAL W: improving the sensitivity of progressive multiple sequence alignment through sequence weighting, position-specific gap penalties and weight matrix choice. Nucleic Acids Res 22:4673-4680

35. Tamura K, Dudley J, Nei M, Kumar S (2007) MEGA4: molecular evolutionary genetics analysis (MEGA) software version 4.0. Mol Biol Evol 24:1596-1599

36. Driever W, Rangini Z (1993) Characterization of a cell line derived from zebrafish (Brachydanio rerio) embryos. In Vitro Cell Dev Biol Anim 29A:749-754

37. Krishan A (1975) Rapid flow cytofluorometric analysis of mammalian cell cycle by propidium iodide staining. J Cell Biol 66:188-193

38. Abu Bakar MF, Mohamad M, Rahmat A, Burr SA, Fry JR (2010) Cytotoxicity, cell cycle arrest, and apoptosis in breast cancer cell lines exposed to an extract of the seed kernel of Mangifera pajang (bambangan). Food Chem Toxicol 48:1688-1697

39. Senturk S, Gursoy-Yuzugullu O, Cingoz B, Akcali KC, Ozturk M (2010) Transforming growth factor-beta induces senescence in hepatocellular carcinoma cells and inhibits tumor growth. Hepatology 52:966-974

40. Pfaffl MW (2001) A new mathematical model for relative quantification in real-time RT-PCR. Nucleic Acids Res 29:e45

41. Tang R, Dodd A, Lai D, McNabb WC, Love DR (2007) Validation of zebrafish (Danio rerio) reference genes for quantitative real-time RT-PCR normalization. Acta Biochim Biophys Sin (Shanghai) 39:384-390

42. McCurley AT, Callard GV (2008) Characterization of housekeeping genes in zebrafish: male-female differences and effects of tissue type, developmental stage and chemical treatment. BMC Mol Biol 9:102
43. Zhang J, Wang X, Zhao Y, Chen B, Suo G et al (2006) Neoplastic transformation of human diploid fibroblasts after long-term serum starvation. Cancer Lett 243:101-108

44. Yabuta N, Onda H, Watanabe M, Yoshioka N, Nagamori I et al (2006) Isolation and characterization of the TIGA genes, whose transcripts are induced by growth arrest. Nucleic Acids Res 34:4878-4892

45. Quinn CM, Kagedal K, Terman A, Stroikin U, Brunk UT et al (2004) Induction of fibroblast apolipoprotein E expression during apoptosis, starvation-induced growth arrest and mitosis. Biochem J 378:753-761

46. Osabe M, Sugatani J, Takemura A, Kurosawa M, Yamazaki Y et al (2009) Up-regulation of CAR expression through Elk-1 in HepG2 and SW480 cells by serum starvation stress. FEBS Lett 583:885-889

47. Brooks RF (1976) Regulation of fibroblast cell cycle by serum. Nature 260:248-250

48. Schaaf MJ, Koopmans WJ, Meckel T, van Noort J, Snaar-Jagalska BE et al (2009) Single-molecule microscopy reveals membrane microdomain organization of cells in a living vertebrate. Biophys J 97:1206-1214

49. Roca FJ, Mulero I, Lopez-Munoz A, Sepulcre MP, Renshaw SA et al (2008) Evolution of the inflammatory response in vertebrates: fish TNF-alpha is a powerful activator of endothelial cells but hardly activates phagocytes. J Immunol 181:5071-5081

50. Luo Y, Weng S, Wang Q, Shi X, Dong C et al (2009) Tiger frog virus can infect zebrafish cells for studying up- or down-regulated genes by proteomics approach. Virus Res 144:171-179

51. Hu MC, Gong HY, Lin GH, Hu SY, Chen MH et al (2007) XBP1 , a key regulator of unfolded protein response, activates transcription of IGF1 and Akt phosphorylation in zebrafish embryonic cell line. Biochem Biophys Res Commun 359:778-783

52. Burns JC, Friedmann T, Driever W, Burrascano M, Yee JK (1993) Vesicular stomatitis virus G glycoprotein pseudotyped retroviral vectors: concentration to very high titer and efficient gene transfer into mammalian and nonmammalian cells. Proceedings of the National Academy of Sciences of the USA 90: 8033-8037

53. Khammanit R, Chantakru S, Kitiyanant Y, Saikhun J (2008) Effect of serum starvation and chemical inhibitors on cell cycle synchronization of canine dermal fibroblasts. Theriogenology 70:27-34

54. Goissis MD, Caetano HV, Marques MG, de Barros FR, Feitosa WB et al (2007) Effects of serum deprivation and cycloheximide on cell cycle of low and high passage porcine fetal fibroblasts. Reprod Domest Anim 42:660-663

55. de Barros FR, Goissis MD, Caetano HV, Paula-Lopes FF, Peres MA et al (2010) Serum starvation and full confluency for cell cycle synchronization of domestic cat (felis catus) foetal fibroblasts. Reprod Domest Anim 45:38-41

56. Dalman A, Eftekhari-Yazdi P, Valojerdi M, Shahverdi A, Gourabi $\mathrm{H}$ et al (2009) Synchronizing cell cycle of goat fibroblasts by serum starvation causes apoptosis. Reprod Domest Anim 45(5):e46-e53

57. Kues WA, Anger M, Carnwath JW, Paul D, Motlik J et al (2000) Cell cycle synchronization of porcine fetal fibroblasts: effects of serum deprivation and reversible cell cycle inhibitors. Biol Reprod 62:412-419

58. Fukami-Kobayashi J, Mitsui Y (1999) Overexpression of proliferating cell nuclear antigen in mammalian cells negates growth arrest by serum starvation and cell contact. Jpn J Cancer Res 90:286-293

59. Liu YC, Chen GS, Liu WL, Wen SF (1995) Estimation of PCNA mRNA stability in cell cycle by a serum-deprivation method. J Cell Biochem 57:641-646 
60. Tominaga K, Magee DM, Matzuk MM, Pereira-Smith OM (2004) PAM14, a novel MRG- and Rb-associated protein, is not required for development and T-cell function in mice. Mol Cell Biol 24:8366-8373

61. Saxena UH, Powell CM, Fecko JK, Cacioppo R, Chou HS et al (2009) Phosphorylation by cyclin C/cyclin-dependent kinase 2 following mitogenic stimulation of murine fibroblasts inhibits transcriptional activity of LSF during G1 progression. Mol Cell Biol 29:2335-2345

62. Rizwani W, Alexandrow M, Chellappan S (2009) Prohibitin physically interacts with MCM proteins and inhibits mammalian DNA replication. Cell Cycle 8:1621-1629

63. Xu J, Morris GF (1999) p53-mediated regulation of proliferating cell nuclear antigen expression in cells exposed to ionizing radiation. Mol Cell Biol 19:12-20

64. Scian MJ, Carchman EH, Mohanraj L, Stagliano KE, Anderson MA et al (2008) Wild-type p53 and p73 negatively regulate expression of proliferation related genes. Oncogene 27:2583-2593

65. Lee Y, Chen Y, Chang LS, Johnson LF (1997) Inhibition of mouse thymidylate synthase promoter activity by the wild-type p53 tumor suppressor protein. Exp Cell Res 234:270-276

66. Leask A, Holmes A, Black CM, Abraham DJ (2003) Connective tissue growth factor gene regulation. Requirements for its induction by transforming growth factor-beta 2 in fibroblasts. J Biol Chem 278:13008-13015

67. Iizuka N, Tsunedomi R, Tamesa T, Okada T, Sakamoto K et al (2006) Involvement of c-myc-regulated genes in hepatocellular carcinoma related to genotype-C hepatitis B virus. J Cancer Res Clin Oncol 132:473-481

68. Guida T, Salvatore G, Faviana P, Giannini R, Garcia-Rostan G et al (2005) Mitogenic effects of the up-regulation of minichromosome maintenance proteins in anaplastic thyroid carcinoma. J Clin Endocrinol Metab 90:4703-4709 